\title{
Soil Properties and the Abundance of Ironwood (Eusideroxylon zwageri Teijsm.\& Binn.) Varieties in Jambi, Indonesia
}

\author{
Bambang Irawan
}

\author{
Department of Forestry, Faculty of Forestry, University of Jambi \\ Campus Pinang Masak, Jambi-Muara Bulian Main Road, KM. 15 Mendalo Darat-Jambi, Indonesia, 36361
}

Received August 13, 2015/Accepted November 26, 2015

\begin{abstract}
Two series of a study on the correlation between soil properties and distribution of ironwood(Eusideroxylon zwageri Teijsm.\& Binn.) varieties had been conducted in Senami, a natural forest stand, Jambi, Indonesia. The first was using purposive random sampling. The samples were taken from the locations where the E. zwageri varieties naturally grow in the depth of 0-30 cm and 30-60 cm. The number of composite samples was 18 which were analyzed for chemical soil properties. The second study was conducted using systematic sampling where 64 soil cores were collected from 3 different soil depths namely $0-20 \mathrm{~cm}, 20-40 \mathrm{~cm}$, and 40-60 cm. The physical soil properties were analyzed from the 64 soil samples. The research results revealed that the drainage among E. zwageri varieties varied from poor conditions to moderate, while the bulk density was slightly different, from very low to low. The results also show that E. zwageri varieties are able to grow in almost any soil textures. There is no specific correlation between chemical soil properties and distribution of E. zwageri varieties. All varieties grow at almost the same condition of chemical soil properties except var. grandis.
\end{abstract}

Keywords: Eusideroxylon zwageri, natural distribution, soil properties, varieties

*Correspondence author, email: irawanbam@yahoo.com, ph.:+62-741-583111

\section{Introduction}

Bulian/ulin/belian/borneo ironwood (ironwood) (Eusideroxylon zwageri Teijsm. \& Binn.), synonymous with Bihania borneensis Meissner and Eusideroxylon lauriflora Auct., belongs to the family of Lauraceae, tribus of Cryptocaryeae, and subtribus of Eusideroxylineae (Kostermans 1957). Irawan (2005) reported that in the natural forest, morphological structures of E. zwageri vary significantly for leaves, seeds, and stems (bark surface). They can be used as keys to identify E. zwageri varieties. Four varieties of E. zwageri namely-var. zwageri, var. ovoidus, var. exilis, and var. grandis-all of which are significantly different from one another, can be distinguished.

The habitat of E. zwageri is lowland forests $(500 \mathrm{~m}$ and rarely reaching $625 \mathrm{~m}$ above sea level). E. zwageri naturally distributed in Sumatra, Kalimantan, and some small islands such as Tawi-Tawi (Philippines), Banka and Billiton. It is a scattered component of the Dipterocarp forests. In some localities it forms a single dominant variant, in flat or sloping terrain, and also occurs in old secondary forests (Merril 1923; De Boer 1939; De Wit 1949; Beekman 1949; Suselo 1987; MacKinnon et al. 1997). The natural distribution of $E$. zwageri is mainly in the regions of Sumatra and Borneo.
Whitmore (1984) reported that these regions lie on the Sunda shelf at the heart of the western rain-forest block and have close floristic similarity.

E. zwageri grows well in humid climates and it also could grow in places with short dry seasons (Koopman \& Verhoef 1938). Soedibja (1952) stated that E. zwageri is a shadebearer species when immature. It is especially found in sandy soil and requires a fairly drained soil with a wet climate. In addition, Soerianegera (1974) reported that E. zwageri could be found in areas with dry sub-humid climates and humid climates with precipitation of 2,000-6,000 mm year ${ }^{-1}$. Background and scientific problems Tuyt (1939) reported that $E$. zwageri is principally a shade-bearing tree and grows well in a wet soil. These 2 factors must be taken into consideration during the laying out of a plantation. The best results have been obtained by planting out the trees in shaded rows under old secondary forest or primary forest. In general, more shade-tolerant species exhibit a greater survivorship than less shade-tolerant species in light-limiting environments (Oliver \& Larson 1990; Kobe \& Coates 1997).

Soedibja (1952) reported that gradual exposure to sunlight as the E. zwageri seedlings increase in size does no harm, but too much light-and especially exposure immediately to full sunlight-check growth and the seedlings 
may die. After 12 years the E. zwageri must be cleaned from the secondary forest. Height increases with the depth of the clay/iron pan, the slope of the ground also affects height growth.

The wide soil types of natural distribution of E. zwageri also reported by Gresser (1919) that most E. zwageri forests occur on level areas along rivers and adjacent hills. The vicinity of a river is not necessary, however, where the soil consists of loamy sand; the forests are found along rivers as well as on pure sand. Additionaly, De Wit (1949) reported that soils which are temporarily inundated, marshy or waterlogged spots are always avoided by E. zwageri.

These soil variations seem to be correlated with the distribution of E. zwageri varieties. The preliminary data obtained that the distribution of E. zwageri varieties scaterred in small clusters (Irawan 2005). To find the correlation between soil properties and distribution of $E$. zwageri varieties, this study was conducted. Another reason is the knowledge on the soil properties, especially related to the distribution of E. zwageri varieties is really important for future management of E. zwageri both in natural and plantation stands since the potential growth rate of $E$. zwageri variety is also significantly different (Irawan 2005; 2012).

\section{Methods}

The study was conducted twice for about 5 months at Senami, a natural habitat of E. zwageri, in Jambi, Indonesia. The size of the study area was about 15,830 ha. Soil analysis was conducted at the Chemistry and Soil Fertility Laboratory of Agriculture Faculty at Jambi University, Indonesia.

The materials that were used were some samples of trees and seedlings from the natural forest stand of $E$. zwageri. The instruments were compass, GPS, abney level, tape, Munsell book, soil borer, texture knife, data sheet, rope, and stationery. The first research had been conducted by direct observation in the field using purposive random sampling. The soil samples were taken from 2 different soil depths that were $0-30 \mathrm{~cm}$ and $30-60 \mathrm{~cm}$ from the soil where the $E$. zwageri varieties could be found.

The soil samples were taken about $30 \mathrm{~cm}$ from the $E$. zwageri trees individual soil cores from different locations which had similar color and texture were mixed thoroughly. A sub-sample of the soil mixture was removed and placed in a soil sample bag. This sample is commonly referred to as a composite sample. The number of composite samples which were analyzed was 18 .

The second soil research was conducted using systematic plot survey. The number of soil cores was 64. The soil samples were taken from 3 different soil depths between 0 and $60 \mathrm{~cm}$. The depths were divided based on physical structures such as color and texture. The parameters which were observed were mostly physical soil properties, while the first soil research was conducted to analyze chemical soil properties.

Variables and statistical analysis The variables which were observed in this research were: (a) soil altitude, (b) slope (c) drainage, (d) bulk density, (e) effective depth, (f) soil texture, (g) soil moisture, (h) acidity, (i) macro elements namely nitrogen $(\mathrm{N})$, phosporus $(\mathrm{P})$, potassium $(\mathrm{K})$, carbon $(\mathrm{C})$, natrium $(\mathrm{Na})$, calcium $(\mathrm{Ca})$, and magnesium $(\mathrm{Mg})$, (j) base saturation, and $(\mathrm{k})$ cation exchange capacity (CEC).

\section{Results and Discussion}

The results of soil research, which were divided into physical and chemical soil properties, are presented in Table 1, Table 2, and Table 3.

Physical soil properties soil and vegetation analysis-soil property analysis The physical soil properties at the research site obtained information that the physical condition is quite good to support the growth of flora including $E$. zwageri. The dominant soil texture is sandy clay loam, sandy clay, and clay. This means that the composition of sand, silt, and clay fraction is comparable. Therefore, the ability of the soil to store water, minerals, and nutrients to supply the plant is relatively good. As mentioned by Ohta and Syarif (1996), that soil texture is the most important factor affecting nutrient status and productivity in the major soils under lowland dipteocarp forest.

The research results show that $E$. zwageri is able to grow in almost any soil textures, from sandy soil to clay soil. It is not just restricted to sandy soil of tertiary origins (Gresser 1919; Witkamp 1925). It even grows more widespread in terms of soil type than in investigation results reported by Suselo (1981). However, E. zwageri is sparsely present on loamy sand. There is only one plot where a specimen of $E$. zwageri (var. zwageri) was found compared to 17 plots where E. zwageri was absent.

Var. exilis grew mostly in sandy clay, sandy clay loam, and clay soil textures while var. ovoidus was able to grow in

Table 1 Physical soil properties that are separated based on E. zwageri varieties

\begin{tabular}{|c|c|c|c|c|c|}
\hline Varieties & Slopes (\%) & Altitudes (m asl) & Drainages & $\begin{array}{l}\text { Bulk densities } \\
\left(\mathrm{g} \mathrm{cm}^{-3}\right)\end{array}$ & $\begin{array}{l}\text { Effective } \\
\text { depths (cm) }\end{array}$ \\
\hline Var. exilis & $0-30(16.3)$ & $31-122(64.8)$ & Poor & $1.20-1.35$ & 35 \\
\hline Var. ovoidus & $10-30(19.7)$ & $31-143(85.0)$ & Poor to moderate & 0.90 & $30-35$ \\
\hline Var. zwageri & $0-40(20.4)$ & $31-134(71.2)$ & Poor & $0.89-1.20$ & $30-40$ \\
\hline Var. grandis & $0-35(23.3)$ & $53-87(66.7)$ & Poor to moderate & $0.75-1.30$ & $30-35$ \\
\hline No E. zwageri & $0-60(25.7)$ & 39-177 (97.1) & - & & \\
\hline
\end{tabular}

The number in parentheses is the average value of slope (\%) or altitude (m asl) 


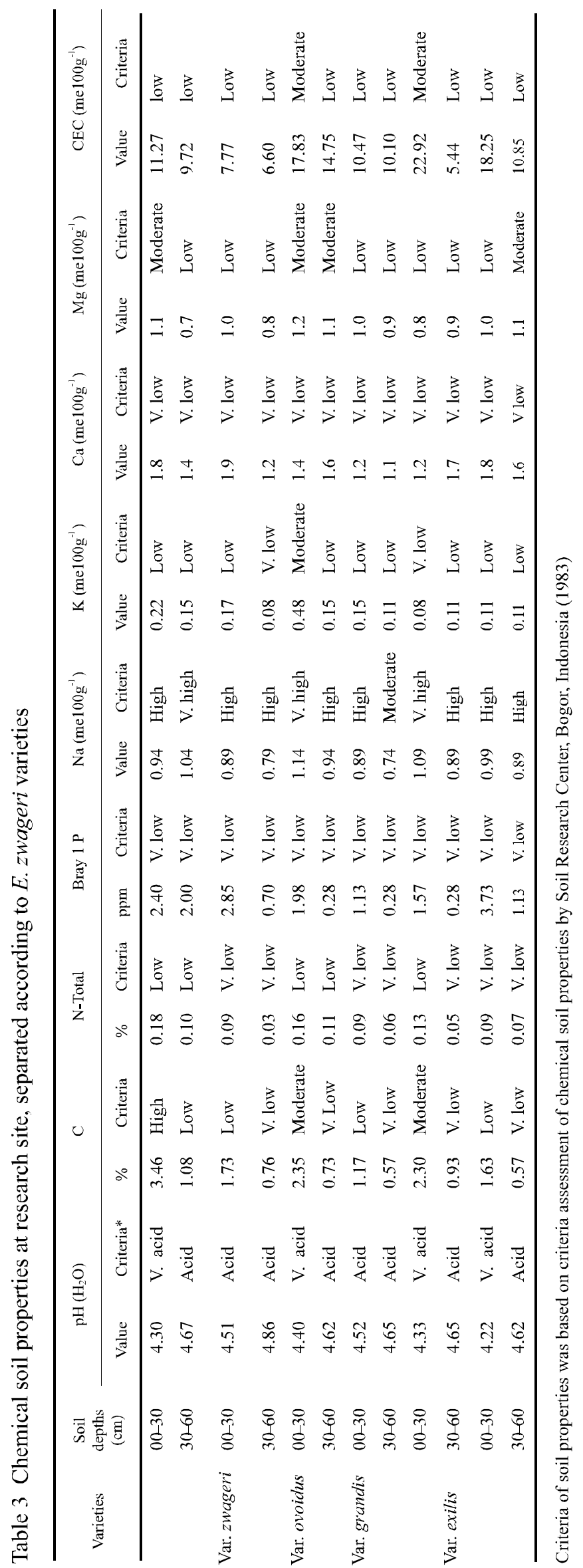


sandy clay loam, sandy loam, clay, and clay loam. Var. $z$ wageri was the variety that grew separately in almost all soil varieties from sandy clay to sandy soil. It even grew in loamy sand where other varieties were absent. Most of the var. grandis grew in sandy clay loam and sandy clay; however, it could also be found in clay and sandy loam. Loamy sand was the soil texture that seems to be least appropriate for $E$. zwageri. Table 1 shows that there were 17 plots of loamy sand soil where E. zwageri was absent and only 1 plot of this soil texture where $E$. zwageri was present (var. zwageri).

Chemical soil properties The results of soil analysis on chemical properties are presented in Table 3 . They show that in general, the chemical soil condition in the research site was poor. $\mathrm{pH}\left(\mathrm{H}_{2} \mathrm{O}\right)$ varied from very acid to acid, the nitrogentotal was very low to low, potassium was very low to moderate, calcium was very low, magnesium low to moderate, Bray $1 \mathrm{P}$ was very low, natrium was high to very high, and CEC was low to moderate.

There is no specific correlation between chemical soil properties and E. zwageri varieties. All varieties grow at almost the same condition of chemical soil properties except var. grandis, which grows in slightly worse soil conditions, especially with regards to phosphorus (Table 3 ).

Soil type at the research site was mostly dominated by ultisols which is included into Hapludults subgroup (Masano \& Omon 1983). Van Wambeke (1991) explained that ultisols of tropical regions vary considerably in their chemical characteristics. Guidelines on the management of their fertility can only be given when restricting their range to the low-activity clay soils (CEC less than $24 \mathrm{cmol}(+) \mathrm{kg}^{-1}$ clay and limiting the discussion to cations and phosphate).

Chemical soil properties at the research site are not as good as physical soil properties. As mentioned in many publications, the soil of tropical forests has poor soil properties (Lamprecht 1989; Sanchez 1989; van Bremen et al. 1990; Terborgh 1992). Most of the nutrients, especially essential elements, are at low to very low levels as described by van Wambeke (1991); therefore, even though the soil is able to store the nutrients, the quantity is not enough. The condition is becoming worst since the $\mathrm{pH}$ value is also very acid to acid. In the soil that had a low $\mathrm{pH}$ value, some of the essential elements such as $\mathrm{P}$ are not available for trees because it will react with Al. The CEC of the soil in the research site is also low to moderate. This means that the ability of the soil to exchange cations such as $\mathrm{K}, \mathrm{N}, \mathrm{P}, \mathrm{Mg}$ is also in the range between low and moderate; therefore, the ability of the soil to obtain available nutrients in cation form is at the same level (low to moderate) (Table 3).

The results of this experiment on chemical soil properties also support results of an experiment that was conducted by Suselo (1981) that E. zwageri grows on clay-loam soils. The soil is moderately acid with quite a high level of carbon but a moderate $\mathrm{C} / \mathrm{N}$ ration. It contains very low concentrations of phosphorus, sodium, and magnesium but a fairly high concentration of potassium. The total exchangeable base is very low and the cation exchange capacity quite high. Additionally, Masano and Omon (1983) found that soil type in that area is dominated by ultisols with the texture of sandy clay loam. The rate of soil fertility is low. This is indicated by low levels of nitrogen, phosphorus, and potassium.

There is no knowledge about the exact relationship between the various varieties of $E$. zwageri to certain kinds and levels of soil nutrients, but correlation between levels of soil nutrients and species richness could be used to explain the formation of new varieties, including E. zwageri varieties. Asthon (1965) mentioned that soil variability, humidity, rooting depth, $\mathrm{pH}$, drainage and slope, degree of leaching, and depth of humus cause variations in the structure and floristic composition of the forest. Additionally, Burnham (1984) argued that next to climate, soil conditions constitute the most important factor in the distribution of plants.

Some researchers found that there is a correlation between poor soil properties and the diversity of a tropical forest. The low level of soil fertility seems to be the reason why tropical forests contain an enormous number of tree species. Species richness is primarily determined by the abundance of physical environmental resources, and is enhanced by small-scale heterogeneity in those resources, which are limiting to plant survival and growth (Tilman 1982; 1986).

Ashton (1989), who had conducted an experiment in Borneo, concluded that the pattern of variation in tree species composition was correlated with concentrated, $\mathrm{HCl}-$ extractable phosphorus and magnesium where the values are below c. $200 \mathrm{ppm}$ and c. $1200 \mathrm{ppm}$. Also, below the same nutrient threshold there was a positive linear correlation between species richness and soil magnesium. Maximum species richness was attained at about the same threshold, above which species richness became negatively correlated with both nutrients. In the research sites phosphorus, especially is very low and magnesium is low to moderate. According to Ashton (1989), those elements could be used as indicators of species richness.

There are many other researchers who explained the relationship between soil fertility and plant diversity. Most of them found that plant diversity is decreasing with the increase in soil fertility. For example, Rajaniemi (2002) concluded that random thinning, shoot and root competition may all have contributed to decreased species richness and diversity following fertilization (DiTommaso \& Aarssen 1989; Gough et al. 2000; Aarssen 2001; Rajaniemi 2003; Rajaniemi et al. 2003).

The poor soil properties do not create a new species or variety but they create the potential for new genovarieties to grow. The poor soil properties prevent certain tree species from growing vigorously and dominantly in the certain area over a short time. Therefore, less competition among species occurs and more space and light is available. Those conditions let some new species build up. The ability of the new species or varieties to compete and utilize available space, light, water and limited nutrients that are provided by "poor soil properties" will determine the existence of the variety or species.

Tilman (1982) predicted that plant species diversity will increase as 2 or more resources increase in concentration from a low base, and also increasingly vary in space, because niche space and opportunities for coexistence of nutrient specialist increase. One or a few species with high growth 
rates will outcompete others for light and dominate the canopy, thereby suppressing species richness. Additionally, Ashton (1998) demonstrated that the peak of species richness along a nutrient occurs towards the low end of the nutrient range.

E. zwageri could be found not only in the flat soil condition but also in hilly soil with the altitude around 31-143 m asl. var. exilis was able to grow on hilly soil with altitude and slope of 31-122 m and 0-30\% (average altitude was $64.8 \mathrm{~m}$ and slope was $16.3 \%$ ), respectively. Var. ovoidus could be found at a higher altitude, with an average of $85 \mathrm{~m}$ (31-143 m asl) and slope of 10-30\%. Var. zwageri could be found at locations between both varieties. Its altitude was $31-134 \mathrm{~m}$ with a mean of $71.2 \mathrm{~m}$ and slope of $0-40 \%$ with an average slope of $20.4 \%$. Var. grandis was able to grow at a lower altitude. It could be found at 53-87 $\mathrm{m}$ asl $(66.7 \mathrm{~m})$ and slope of $0-35 \%(23.3 \%)$. However, there were some areas with altitude of 39-177 m (97.1 m asl) and slope of 0-60\% (25.7\%) where E. zwageri could not be found (Figure 1, Figure 2). The drainage among E. zwageri varieties varied from the poor conditions for var. zwageri and var. exilis varieties and poor to moderate for var. grandis and var. ovoidus varieties, while the bulk density was slightly different, from very low to low.

Altitude and slope influence the distribution of $E$. zwageri. E. zwageri could be found mostly below $160 \mathrm{~m}$ asl with maximal slope of $40 \%$ (Figure 1, Figure 2). This condition seems to be a result of the seed dispersal pattern mentioned by Howe (1990), which is that the behavior of dispersal agents determines the pattern of seed distribution and consequently defines the conditions under which seedlings live or die. Due to big and heavy fruit and seed, $E$. zwageri's seeds are distributed around the forest area by gravity (slope); therefore, most of the seeds will accumulate on cracks or in the lower part of the forest (Burton et al. 1981).

Monkeys, orangutan, and porcupines also help to distribute seeds but this could happen only in some cases (Gautier-Hion et al. 1985; Kostermans et al. 1994). Ovoidus

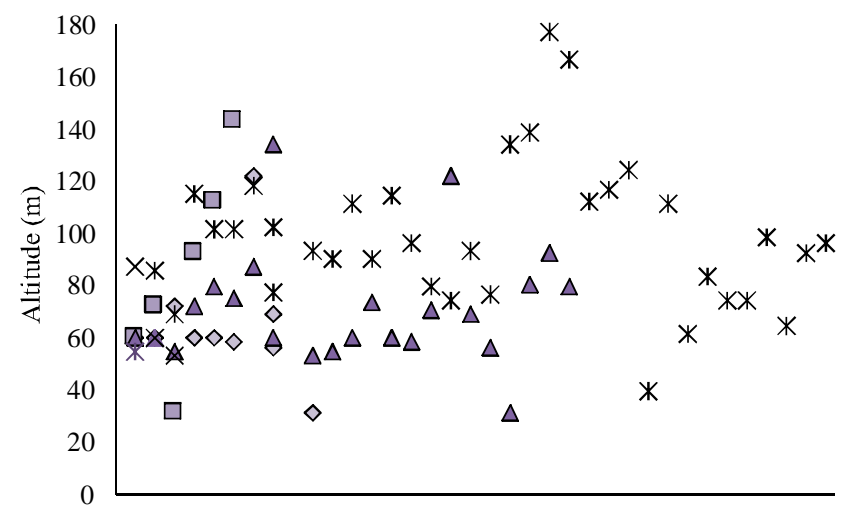

Figure $1 E$. zwageri's varieties distribution according to altitude. exilis $(\diamond)$, ovoidus $(\square)$, zwageri $(\Delta)$, grandis $(X)$, absent $(X)$ is the variety that is able to grow at a higher altitude, followed by zwageri, exilis, and grandis. This distribution pattern seems to be affected by the form and the weight of the seeds (Gautier-Hion et al. 1985; Hladik \& Miquel 1990). Ovoidus is the variety that had smallest and lightest seeds while grandis had the biggest and the heaviest seeds; therefore, case by case, it is easier for monkeys and porcupines to bring ovoidus's seeds higher than grandis's seeds. Gravity also works in the same direction, so the heavier seeds will have greater potential energy to roll down than the lighter ones. This result could explain why E. zwageri prefer to grow on slightly undulating topography as mentioned by Whitten $e t$ al. (2000).

\section{Conclusion}

E. zwageri could be found not only in the flat soil condition but also in hilly soil with the altitude around 31-143 m asl. E. zwageri is able to grow in almost any soil textures, from sandy soil to clay soil. There is no specific correlation between chemical soil properties and E. zwageri varieties. All varieties grow at almost the same condition of chemical soil properties except var. grandis, which grows in slightly worse soil conditions, especially with regards to phosphorus.

\section{References}

Aarssen LW. 2001. On correlations and causations between productivity and species richness in vegetation: predictions from habitat attributes. Basic and Applied Ecology 2(2):105-114. http://dx.doi.org/10.1078/14391791-00041.

Ashton PS. 1965. Notes on the formation of rational classification of floristic and structural variation within the mixed dipterocarp forests of Sarawak and Brunei, for forestry and land use planning. Symposium on ecological research in humid tropics vegetation, 185-197. Kuching, Malaysia.

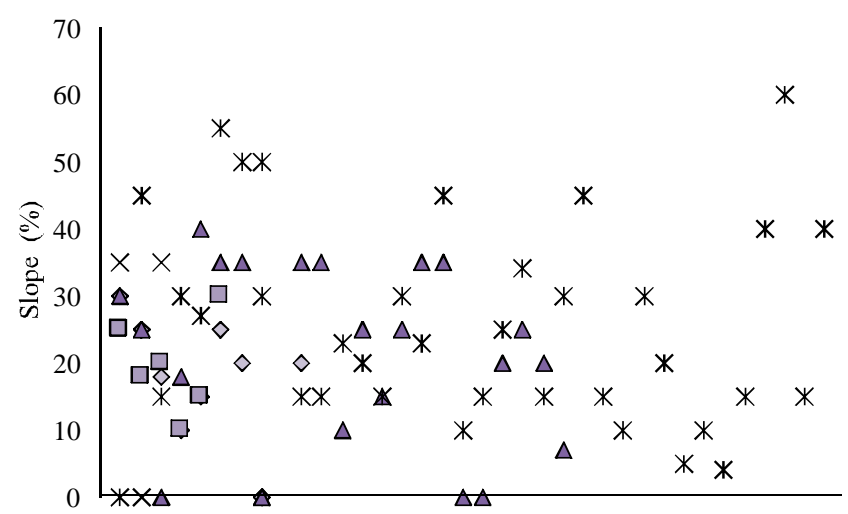

Figure 2 E. zwageri's varieties distribution according to slope. exilis $(\diamond)$, ovoidus $(\square)$, zwageri $(\triangle)$, grandis $(X)$, absent $(X)$. 
Ashton PS. 1989. Species richness in tropical forests. In: Holm-Nielsen LB, Nielsen IC, Balslev, H, editors. Tropical Forests: Botanical Dynamics, Speciation and Diversity. London: Academic Press. http://dx.doi.org/ 10.1016/b978-0-12-353550-4.50026-5.

Ashton PS. 1998. Niche specificity among tropical trees: a question of scales. In: Newbery DM, Brown N, Prins HH, editors. Dynamics of Tropical Communitie. Oxford: Blackwell Scientific Publication.

Beekman HAJM. 1949. Houtteelt in Indonesie (Silviculture in Indonesia). Wegeningen: Publicate van de Stichting`Fonds Landbouw Exportbureaue`1916-1918.

Burnham CP. 1984. The forest environment: Soils. In: Whitmore TC, editor. Tropical Rain Forests of The Far East. Oxford: Clarendon Press.

Burton M, Franco J, Gennaro J, Johnson H, Mitchell A, Yoho JG. 1981. The International Book of The Forest. London: Mitchell Beazley Publishers.

De Boer WAP. 1939. Ontwikkeling van de productiemogelijkheden der Bosschen in de Butengewesten. Tectona 32: 389-430.

De Wit HCD.1949. Spicilegium malaianum. Bulletin of the Botanical Gardens Buitenzorg 18(3):181-212.

DiTommaso A, Aarssen LW. 1989.Resource manipulation in natural vegetation: a review. Vegetatio 84:9-29. http://dx.doi.org/10.1007/BF00054662.

Gautier-Hion A, Duplantier JM, Quris R, Feer F, Sourd C, Decoux JP, Dubost G, Emmons L, Erard C, Hecketweiler P, Moungazi A, Roussilhon C,Thiollay JM. 1985. Fruit characters as a basis of fruit choice and seed dispersal in a tropical forest vertebrate community. Oecologia 65:159-165.http://dx.doi.org/10.1007/BF00378906.

Gough L, Osenberg CW, Gross KL, Collins SL. 2000. Fertilization effects on species density and primary productivity in several herbaceous plant communities. Oikos 89:428-439.http://dx.doi.org/10.1034/j.16000706.2000.890302.x

Gresser E. 1919. Bijdragen resumeerend repport over het voorkomen van ijzerhout op de olieterreinen Djambi I. Tectona 12:283-304.

Hladik A, Miquel S. 1990. Seedling types and plant establishment in an african rain forest. In: Bawa KS, Hadley M, editors. Reproductive Ecology of Tropical Forest Plants. UNESCO Paris: The Parthenon Publishing Group.

Howe HF. 1990. Seed dispersal by birds and mammal: Implications for seedling demography. In: Bawa KS, Hadley M, editors. Reproductive Ecology of Tropical Forest Plants: UNESCO Paris: The Parthenon Publishing Group.
Irawan B. 2005. Ironwood (Eusideroxylon zwageri Teijsm. \& Binn.) and its varieties in Jambi, Indonesia. Göttingen: Cuvillier Verlag.

Irawan B. 2012. Growth performance of one year old seedlings of ironwood (Eusideroxylon zwageri Teijsm. \& Binn.) varieties. Jurnal Manajemen Hutan Tropika 18(3):184-190. http://dx.doi.org/10.7226/jtfm.18.3.184

Kobe RK, Coates KD. 1997. Models of sapling mortality as a function of growth to characterize inter specific variation in shade tolerance of eight tree species of Northwestern British Columbia. Canada Journal of Forestry 27:227-236.http://dx.doi.org/10.1139/cjfr-27$2-227$

Koopman MJF, Verhoef L. 1938. Eusideroxylon zwageri, the ironwood of Borneo and Sumatra. Tectona 31:381-399.

Kostermans AJGH. 1957. Lauraceae. Communication of The Forest Research Institute. Indonesia No. 57. Bogor: Balai Besar Penjelidikan Kehutanan.

Kostermans AJGH, Sunarno B, Martawijaya A, Sudo S. 1994. Eusideroxylon zwageri Teisjm. and Binnend. In: Soerianegara I, Lemmens RHMJ, editors. Plant Resources of South-East Asia 5 (1). Timber trees: major commercial timbers. Bogor: PROSEA.

Lamprecht H. 1989. Silviculture in The Tropics: Tropical Forest Ecosystems and Their Tree Species-Possibilities and Methods for Their Long-Term Utilization. Technical cooperation-Federal Repubic Germany.

MacKinnon K, Hatta G, Halim H, Mangalik A. 1997. The ecology of Kalimantan. The ecology of Indonesia series Volume III. Oxford: Oxford University Press.

Masano R, Omon M. 1983. Observation on natural regeneration of Eusideroxylon zwageri T. et B. in Senami forest complex, Jambi. Laporan Balai Penelitian Hutan No. 410. Pusat Penelitian dan Pengembangan Kehutanan.

Merril ED. 1923. An Enumeration of Philippine Flowering Plants Vol. 2. Manila: Bureau of Printing.

Ohta S, Syarif E. 1996. Soils under lowland dipterocarp forests-characteristics and classification. In: Shulte A, Schöne D, editors. Dipterocarp Forest Ecosystems: Towards Sustainable and Management. World Scientific. http://dx.doi.org/10.1142/97898142 61043_0002.

Oliver WW, Larson BC. 1990. Forest Stand Dynamics. New York: Mc. Grew-Hill.

Rajaniemi TK. 2002. Why does fertilization reduce plant species diversity? Testing three compettion-based hypotheses. Journal of Ecology 90:316-324. http://dx.doi.org/10.1046/j.1365-2745.2001.00662.x 
Rajaniemi TK. 2003. Explaining productivity-diversity relationships in plants: mini review. Oikos 101:449-457. http://dx.doi.org/10.1034/j.1600-0706. 2003.12128.x

Rajaniemi TK, Allison VJ, Goldberg DE. 2003. Root competition can cause a decline in diversity with increased productivity. Journal of Ecology 91:407-416.http://dx.doi.org/10.1046/j.1365-2745. 2003.00768.x

Sanchez PA. 1989. Soils. In: Lieth H, Werger MJA, editors. Ecosystems of The World. Tropical rain forest Ecosystems. Amsterdam-Oxford-New York-Tokyo: Elsevier. http://dx.doi.org/10.1016/B978-0-444-427557.50010-9.

Soedibja RS. 1952. Penjelidikan tentang tumbuh dan ekologi kaju besi (Eusideroxylon zwageri T. et B.) di lingkungan hutan Semandai (Palembang). Rimba Indonesia 1(5):215-223.

Soerianegara I. 1974. Ecological researches relevant to current silviculture problems. coordinated study of lowland forest of Indonesia. Bogor: BIOTROP and IPB.

Suselo TB. 1981. Preliminary Report on Ecological Studies of Eusideroxylon zwageri T. and B. in Jambi, Sumatra. Bogor: BIOTROP.

Suselo TB. 1987. Autecology of Eusideroxylon zwageri T. \& B. (Lauraceae) as applied to forest regeneration. In: Proceeding Symposium of Forest Regeneration in South East Asia. Bogor: BIOTROPS Secial Publication No. 25.
Terborgh J. 1992. Diversity and The Tropical Rain Forest. New York: A division of HPHLP, Scientific American Library.

Tilman D. 1982. Resources competition and community structure. New Jersey: Princeton University Press.

Tilman D. 1986. Evolution and differentiation in terrestrial plants communities. The important of the soil resource: light gradient. In: Diamon J, Case TJ, editors. Community ecology. New York: Harper and Row.

Tuyt P. 1939. Schaduwrijen cultuur van ijzerhout in de residente Palembang (Strip planting of ironwood). Tectona.DI.XXXII: 805-827.

van Bremen H, Iriansyah M, Andriesse W. 1990. Detailed Soil Survey and Physical Land Evaluation in a Tropical Rain Forest, Indonesia. The Netherlands: The Tropenbos Foundation Ede.

van Wambeke A. 1991. Soils of the Tropics-Properties and Appraisal. New York: Mc. Graw-Hill. Inc.

Whitmore TC. 1984. Tropical Rain Forests of The Far East ( $2^{\text {nd }}$ edition). Oxford: Clarendon Press.

Whitten AJ, Damanik SJ, Anwar J, Hisyam N. 2000. The Ecology of Sumatra. Singapore: Periplus Editions.

Witkamp H. 1925. De ijzerhoutboom als geologische indicator. De tropische Natuur 26:97-103. 